\title{
KEANEKARAGAMAN MAKROFAUNA TANAH DI PERKEBUNAN KOPI DESA BATU KALUNG KECAMATAN MUARA KEMUMU KABUPATEN KEPAHIANG
}

Pariyanto ${ }^{1 *}$, Endang Sulaiman ${ }^{2}$, Bahlul Ihdana ${ }^{3}$

1,2,3Universitas Muhammadiyah Bengkulu, Jl. Bali, Kota Bengkulu, 38119, Indonesia

*Corresponding author, e-mail: pariyantoyanto914@gmail.com

\section{ABSTRACT}

This study aims to determine the diversity of existing soil macrofauna at coffee plantations located at Batu Kalung village, Muara Kemumu subdistrict of Kepahiang regency. This research was conducted in February 2018 at the coffee plantations area. The methods used in this research were pitfall-trap and hand sorting. The result of the study at the site found there are 9 orders of macraofauna consisting of 11 families, 13 species, and 188 spesimen.The species found were Heterometrus lepturus, Scolopendrae morsitans, Trigoniulus corallines, Neocurtilla hexadactylla, Gryllus assimilis, Ceuthophilus maculates, Dolichoderus bituberculatus, Componotus carnelus, Blatta germanica, Blattella orientalis, Odontotaenius disjunctus, Ponthoscolex corethurus, and Hirudo medicinalis. The calculation of soil macrofauna index in coffee plantations found a number of 0.942 . This indicates that that the level of soil macrofauna diversity at the coffee plantations is low. The highest soil macrofauna diversity index was found on Ponthoscolex corethurus, which is 0.146 . In the contrary, the lowest diversity index was found onHeterometrus lepturus species, 0.011 . In addition, The average physics-chemical factor of soil at the coffee plantation was obtained that the soil temperature is $28^{\circ} \mathrm{C}$, soil $\mathrm{pH}$ of 5.8 , and soil moisture of 67

Keywords : Diversity, Coffee Plantation, Soil Macrofauna

\section{PENDAHULUAN}

Fauna tanah merupakan hewan-hewan yang hidup di atas maupun di permukaan tanah, yang terbagi menjadi mirkrofauna, mesofauna dan makrofauna (Nurrohman, 2015). Dari ketiga kelompok hewan tanah tersebut, makrofauna merupakan kelompok yang cukup penting kehadirannya dalam menentukan kualitas tanah (Saputra \& Agustina, 2019). Peran penting makrofauna tanah di lahan pertanian adalah menjaga kualitas lingkungan, pengelolaan tanah yang tidak optimal dapat menyebabakan penurunan kelimpahan dan keragaman makrofauna tanah sehingga berakibat pada terganggunya unsur hara tanah (Yulipriyanto, 2010).

Proses dekomposisi dalam tanah tidak akan mampu berjalan cepat bila tidak ditunjang oleh kegiatan fauna tanah termasuk makrofauna (Hasyimuddin et al. 2017). Keberadaan fauna dalam tanah sangat tergantung pada ketersediaan energi dan sumber makanan untuk kelangsungan hidupnya, seperti bahan organik dan biomassa hidup yang semuanya berkaitan dengan aliran siklus karbon dalam tanah (Hilwan \& Handayani, 2013). Ketersediaan energi dan hara bagi fauna tanah memberikan efek positif untuk perkembangan dan aktivitas fauna tanah dan akan memberikan dampak positif juga bagi kesuburan tanah (Suheriyanto, 2012).

Makrofauna tanah merupakan indikator yang paling sensitif terhadap perubahan dalam penggunaan lahan, sehingga dapat digunakan untuk memprediksi tingkat kualitas lahan. Untuk kelangsungan hidup makrofauna tanah memerlukan 
persyaratan tertentu (Rousseau et al. 2013; Prasetyo et al. 2016). Kondisi lingkungan merupakan faktor utama yang menentukan kelangsungan hidupnya, yaitu: iklim (curah hujan, suhu), tanah (kemasaman, kelembaban, suhu tanah, hara), dan vegetasi (hutan, padang rumput) serta cahaya matahari (Wibowo \& Slamet, 2014).

Makrofauna tanah berperan penting dalam meningkatkan kadar bahan organik tanah. Keberadaan makrofauna tanah dipengaruhi oleh kondisi tanah, salah satunya adalah bahan organik tanah. Meningkatnya keragaman makrofauna tanah di dalam tanah sejalan dengan meningkatnya kandungan bahan organik tanah dan dominasi vegetasi bawah, karena bahan organik tanah maupun sisa-sisa tanaman dari vegetasi bawah dapat dimanfaatkan oleh makrofauna di dalam tanah sebagai sumber makanannya (Imawan, 2013).

Desa Batu Kalung kecamatan Muara Kemumu Kabupaten Kepahiang memiliki luas lahan perkebunan kopi yang mencapai sekitar 1.200 ha (Pemerintah Desa, 2017). Berdasarkan survei prapenelitian ditemukan hewan-hewan makrofauna tanah yang terdapat di perkebunan kopi Desa Batu Kalung sangat beragam yang meliputi berbagai macam jenis arthropoda seperti kaki seribu, jangkrik, rayap, dan berbagai macam jenis cacing tanah seperti, cacing kebun, cacing merah, dan jenis moluska seperti bekicot. Namun Informasi mengenai keanekaragaman makrofauna tanah di perkebunan kopi di desa Batu Kalung, Kecamatan Muara Kemumu, Kabupaten Kepahiang tersebut dirasa masih sangat minim, sehingga sangat perlu untuk dilakukan agar data yang diperoleh dapat dibukukan secara sistematis. Sehingga diharapkan hasil penelitian ini dapat dijadikan acuan untuk penelitian selanjutnya dan informasi bagi masyarakat khususnya petani kopi.

\section{METODE}

\section{Waktu dan Tempat Penelitian}

Penelitian ini dilakukan pada bulan Februari sampai Maret tahun 2018, bertempat di perkebunan kopi desa Batu Kalung Kecamatan Muara Kemumu Kabupaten Kepahiang, dengan koordinat $3^{\circ} 38^{\prime} 58^{\prime \prime} \mathrm{S}-102^{\circ} 43^{\prime} 10^{\prime \prime}$. (Pemerintah Desa, 2017).

\section{Alat dan Bahan}

Alat : toples plastik, pinset, insect-net, kamera, alat-alat tulis, skop, kertas label, thermohygrometer, Alkohol $70 \%$ dan Aquades $50 \mathrm{ml}$.

\section{Metode Penelitian}

Metode yang digunakan dalam penelitian ini adalah dengan melakukan survey dan pengamatan langsung ke lokasi penelitian yang luasnya mencapai \pm 1.200 ha, namun luas area penelitian di batasai hanya 2 ha saja, hal ini dikarenakan lokasi yang demikian luasnya sehingga dalam prakteknya tidak dimungkinkan seluruh elemen untuk diteliti, keterbatasan waktu penelitian, biaya dan sumber daya manusia. Pengambilan sampel hewan makrofauna tanah yang terdapat di permukaan tanah digunakan metode perangkap jebak (pitfall-trap), sedangkan pengambilan hewan di dalam tanah tanah menggunakan metode (hand-shortir). Proses identifikasi dipandu Anwar \& Ginting (2013).

\section{Analisis Data}

Data yang diperoleh akan dianalisis yang meliputi kelimpahan relatif (KR) dan indeks keanekaragaman jenis Shannon-Winner dengan rumus sebagai berikut : 


$$
\mathrm{Kr}=\frac{K i}{\sum k} \times 100
$$

Keterangan :

$\mathrm{Kr} \quad$ : Kelimpahan relative spesies ke i

$\mathrm{Ki} \quad$ : Kelimpahan relative spesies ke i

$\sum \mathrm{k} \quad$ : Jumlah kelimpahan semua spesies

Menurut Habwan (2017) Keanekaragaman jenis yang terdapat dalam komunitas dapat diketahui dari indeks keanekaragaman Shannon-Winner, adalah :

$$
\mathrm{H}^{1}=-\sum \frac{n i}{N} \log \frac{n i}{N}
$$

Keterangan:

$\mathrm{H} \quad$ : Indeks keanekaragaman jenis Shannon-Winner

$\mathrm{Ni} \quad$ : Jumlah individu dari satu jenis i

$\mathrm{N} \quad$ : Jumlah total individu seluruh jenis berikut :

Besarnya indeks keanekaragaman jenis Shannon-Winner didefinisikan sebagai

a. Nilai $H^{1}>3 \quad$ : keanekaragaman spesies tinggi

b. Nilai $H^{1} 1 \leq H^{1} \leq 3$ : keanekaragaman sedang

c. Nilai $H^{1}<1 \quad$ : keanekaragaman rendah

\section{HASIL DAN PEMBAHASAN}

Berdasarkan peneilitian yang telah dilakukan di Desa Batu Kalung Kecamatan Muara Kemumu, Kabupaten Kepahiang ditemukan 13 spesies yang tergolong ke dalam 11 famili dan 9 ordo (Tabel 1).

\begin{tabular}{|c|c|c|c|c|}
\hline \multirow[b]{2}{*}{ Ordo } & \multirow[b]{2}{*}{ Family } & \multirow[b]{2}{*}{ Spesies } & \multicolumn{2}{|c|}{ Keterangan } \\
\hline & & & $\begin{array}{l}\text { Permukaan } \\
\text { tanah }\end{array}$ & $\begin{array}{l}\text { Di dalam } \\
\text { tanah }\end{array}$ \\
\hline Scorpiones & Scorpionoidae & Heterometrus lepturus & $\sqrt{ }$ & \\
\hline Scolopendromorpha & Scolopendridae & Scolopendra morsitans & $\sqrt{ }$ & \\
\hline Pirbolida & Trigoniulidea & Trigoniulus corallinus & $\sqrt{ }$ & \\
\hline Orthoptera & Gryllotalpidae & Neocurtilla hexadactylla & & \\
\hline & $\begin{array}{l}\text { Gryllidae } \\
\text { Rhaphidophoridae }\end{array}$ & $\begin{array}{l}\text { Gryllus assimilis } \\
\text { Ceuthophilus maculatus }\end{array}$ & $\begin{array}{l}\sqrt{ } \\
\sqrt{ }\end{array}$ & \\
\hline Hymenoptera & Formae & $\begin{array}{l}\text { Dolichoderus bituberculatus } \\
\text { Componotus carnelus }\end{array}$ & & $\begin{array}{l}\sqrt{ } \\
\sqrt{ }\end{array}$ \\
\hline Blattodea & Blattidae & $\begin{array}{l}\text { Blattella germanica } \\
\text { Blatta orientalis }\end{array}$ & $\begin{array}{l}\sqrt{ } \\
\sqrt{ }\end{array}$ & \\
\hline Coleoptera & Passalidae & Odontotaenius disjunctus & $\sqrt{ }$ & \\
\hline $\begin{array}{l}\text { Olrgochaeta } \\
\text { Arhynchobdellae }\end{array}$ & $\begin{array}{l}\text { Glossoscolecidae } \\
\text { Hirudinidae }\end{array}$ & $\begin{array}{l}\text { Ponthoscolex corethurus } \\
\text { Hirudo medicinalis }\end{array}$ & $\sqrt{ }$ & $\sqrt{ }$ \\
\hline
\end{tabular}

Tabel 1. Makrofauna Tanah di Perkebunan Kopi Desa Batu Kalung

Famili yang paling banyak ditemukan adalah dari ordo Orthoptera yang diperoleh sebanyak 3 famili yaitu, famili Gryllotalpidae dengan spesies Neocurtilla hexadactylla, famili Gryllidae dengan spesies Gryllus assimilis, dan famili Rhaphidophoridae dengan spesies Ceuthophilus maculatus. Banyaknya hewan orthoptera yang ditemukan pada lokasi penelitian disebabkan karena terdapat 
banyaknya tumbuhan yang menjadi makanan untuk hewan dari ordo orthoptera ini, terutama daun muda kopi dan rerumputan yang tumbuh disekitar perkebunan kopi. Hal ini didukung oleh Peritik (2010) yaitu kebanyakan dari hewan Orthoptera adalah hewan pemakan tumbuh-tumbuhan dan beberapa dari hewan ini adalah hama-hama yang penting pada tanaman budidaya serta menjadi pemangsa, dan sebagai pemakan bahan organik yang membusuk.

Tabel 2. Indeks Kanekaragaman Makrofauna Tanah Di Perkebunan Kopi Desa Batu Kalung

\begin{tabular}{clcc}
\hline No & \multicolumn{1}{c}{ Spesies } & $\mathrm{KR}$ & $\mathrm{H}^{\prime}$ \\
\hline 1 & Heterometrus lepturus & 0,005 & 0,011 \\
2 & Scolopendrae morsitans & 0,015 & 0,027 \\
3 & Trigoniulus corallines & 0,090 & 0,094 \\
4 & Neocurtilla hexadactylla & 0,063 & 0,075 \\
5 & Gryllus assimilis & 0,117 & 0,108 \\
6 & Ceuthophilus maculates & 0,021 & 0,035 \\
7 & Dolichoderus bituberculatus & 0,170 & 0,130 \\
8 & Componotus carnelus & 0,138 & 0,118 \\
9 & Blatta germanica & 0,063 & 0,075 \\
10 & Blattella orientalis & 0,047 & 0,062 \\
11 & Odontotaenius disjunctus & 0,010 & 0,02 \\
12 & Ponthoscolex corethurus & 0,228 & 0,146 \\
13 & Hirudome dicinalis & 0,026 & 0,041 \\
& Jumlah & & 0,942 \\
\hline
\end{tabular}

Keterangan :

$\mathrm{KR}=$ Kelimpahan Relatif ; H’ = Indeks Keanekaragaman Jenis $\left(\mathrm{H}^{\prime}\right)$

Famili yang paling banyak ditemukan adalah dari ordo Orthoptera yang diperoleh sebanyak 3 famili yaitu, famili Gryllotalpidae dengan spesies Neocurtilla hexadactylla, famili Gryllidae dengan spesies Gryllus assimilis, dan famili Rhaphidophoridae dengan spesies Ceuthophilus maculatus. Banyaknya hewan orthoptera yang ditemukan pada lokasi penelitian disebabkan karena terdapat banyaknya tumbuhan yang menjadi makanan untuk hewan dari ordo orthoptera ini, terutama daun muda kopi dan rerumputan yang tumbuh disekitar perkebunan kopi. Hal ini didukung oleh Peritik (2010) yaitu kebanyakan dari hewan Orthoptera adalah hewan pemakan tumbuh-tumbuhan dan beberapa dari hewan ini adalah hama-hama yang penting pada tanaman budidaya serta menjadi pemangsa, dan sebagai pemakan bahan organik yang membusuk.

Penelitian serupa pernah dilakukan oleh Nurrohman et al. (2015) yang memperoleh data makrofuna tanah sebanyak 14 Ordo, 17 famili dan 20 spesies, sehingga apabila dibandingkan dengan penelitian yang dilakukan di Desa Batu Kalung Kecamatan Muara Kemumu Kabupaten Kepahiang jumlah ordo, famili dan spesies lebih sedikit. Hal ini diduga karena adanya pengaruh perbedaan faktor topografi dan faktor abiotik di kedua tempat tersebut, terutama suhu, kadar air, pH tanah, kadar organik tanah dan faktor lingkungan biotik organisme lain di sekitarnya, seperti mikroflora. Hal ini senada dengan pernyataan Wibowo \& Slamet (2014) yang menyatakan bahwa jumlah makrofauna tanah akan semakin banyak dengan semakin bertambahnya bahan organik tanaman karena dapat memberikan perlindungan makrofauna tanah dari tekanan kondisi lingkungan, seperti tingginya suhu, serta dapat melindungi dari serangan predator.

Selanjutnya ordo yang sedikit ditemukan adalah ordo Scorpiones dengan famili Scorpionoidae, ordo Scolopendromorpha dengan famili Scolopendridae, ordo 
Pirbolida dengan famili Trigoniulidea, ordo Coleoptera dengan famili Passalidae, ordo Olrgochaeta dengan famili Glossoscolecidae, dan ordo Arhynchobde dengan famili Hirudinidae. Sedikitnya ditemukan hewan ordo-ordo tersebut disebabkan oleh faktor lingkungan serta habitat yang kurang cocok terhadap kehidupan hewan-hewan teresebut. Hal ini diduga karena habitat adalah lahan perkebunan dengan sedikit serasah dan jumlah cahaya matahari yang banyak sehingga hal ini kurang mendukung kehidupannya.

Menurut Wibowo \& Slamet (2014) ordo Scorpiones, ordo Scolopendromorpha, ordo Pirbolida, ordo Coleoptera, ordo Olrgochaeta dan ordo Arhynchobde cenderung tidak suka terhadap sinar matahari langsung, sehingga lapisan tanah diduga memberikan kondisi yang kurang cocok untuk kehidupannya, selain itu lingkungan merupakan faktor yang paling berpengaruh dalam menentukan penyebaran dan kepadatan makrofauna tanah, karena setiap individu mempunyai adaptasi dan toleransi yang berbeda-beda terhadap habitatnya. Masih menurut Wibowo \& Slamet (2014) yang menjelaskan bahwa makrofauna tanah sangat dipengaruhi oleh faktor lingkungan sekitarnya. Perubahan pada lingkungan akan berdampak pada keberadaan makrofauna tanah, baik secara langsung maupun tidak langsung.

Dari berbagai spesies yang ditemukan pada penelitian ini jumlah individu tertinggi yang didapatkan yaitu pada spesies Pothoscolex corethurus (Cacing tanah) sebanyak 42 individu, hal ini disebabkan karena tingkat kesuburan tanah di lokasi penelitian tersebut cukup subur dan lembab, banyak mengandung bahan sisa-sisa organik, dan juga terdapat serasah-serasah sehingga menyebabkan tingginya populasi cacing tanah. Suin (2012) menyatakan tersedianya makanan yang cukup sangat menentukan pertumbuhan populasi cacing tanah. Cacing tanah sebagai hewan yang ikut berperan dalam proses dekomposisi makanan sisa tanaman, sedangkan bagian yang tidak terserap dikeluarkan berupa material yang lumat. Hewan tanah ini memilih serasah yang ada di tanah. Nurrohman et al. (2015) menambahkan bahwa distribusi bahan organik dalam tanah berpengaruh terhadap cacing tanah, karena terkait dengan sumber nutrisinya sehingga pada tanah miskin bahan organik hanya sedikit jumlah cacing tanah yang dijumpai.

Sedangkan jenis dengan jumlah individu paling sedikit pada penelitian ini yaitu jenis Heterometrus lepturus sebanyak 1 individu, kurangnya terdapat jenis ini diduga pengaruh dari lokasi habitatnya yang digunakan petani sebagai lahan perkebunan kopi sehingga kurang sesuai untuk habitat khususnya dari spesies kalajengking ini, dan menyebabkan minimnya individu yang ditemukan dari jenis hewan tersebut.

Berdasarkan Tabel.2 dari hasil total perhitungan keanekaragaman diperoleh nilai indeks keanekaragaman makrofauna tanah sebesar 0,942 yang artinya indeks keanekaragaman makrofauna tanah terbilang rendah $\left(H^{\prime}<1\right)$. Rendahnya keanekaragaman makrofauna tanah di lokasi penelitian tersebut disebabkan diduga karena akumulasi dari penggunaan pestisida sintesis yang digunakan secara terus menerus sehingga menurunkan jumlah keanekaraman jenismakrofauna tanah. Hal ini sesuai dengan pernyataan Nurohman et al. (2015) bahwa penggunaan pestisida terus menerus dapat menurunkan jumlah keanekaragaman jenis makrofauna terutama pada lahan perkebunan kopi dan coklat. Jika dibandingkan dengan penelitian Wibowo \& Slamet (2014) nilai indeks keragaman jenis yang diperoleh cukup tinggi yaitu sebesar 2,52, hal ini dikarenakan kondisi vegetasi yang beragam/heterogen di berbagai tipe tegakan vegetasi. Berbeda dengan penelitian di perkebunan kopi desa Batu Kalung Kecamatan Muara Kemumu yang memiliki tipe vegetasi homogen, 
sehingga diperoleh indeks keragaman jenis yang rendah. Selain itu diduga rendahnya keanekaragaman jenis ini karena habitat asli dipengaruhi oleh perubahan fungsi hutan ke lahan pertanian, sehingga semakin berkurangnya bahan organik dan serasah-serasah untuk makanan dan tempat beraktivitas makrofauna tanah (Wibowo \& Slamet, 2014).

Spesies dengan indeks keragaman jenis paling tinggi yaitu pada spesies Ponthoscolex corethurus dengan indeks keragaman jenisnya sebesar 0,146 , tingginya indeks keanekaragaman jenis pada cacing tanah disebabkan oleh faktor fisik tanah yang lembab dan banyak mengandung bahan organik sehingga banyaknya ditemukan hewan tersebut. Sugiyarto et al. (2000) menjelaskan kandungan air atau kelembaban tanah akan meningkatkan nilai indeks diversitas dari cacing Ponthoscolex sp. Hanafiah (2012) menambahkan bahwa cacing tanah merupakan hewan pemakan tanah dan bahan organik segar di permukaan tanah, masuk (sambil menyeret sisa-sisa tanaman) ke liangnya, kemudian mengeluarkan kotorannya di permukaan tanah. Aktifitas naik turunnya cacing ini berperan penting dalam pendistribusian dan pencampuran bahan organik dalam solum tanah, yang kemudian berpengaruh positif terhadap kesuburan tanah, baik secara fisik, kimia, maupun biologis.

Spesies dengan indeks keragaman jenis paling rendah yaitu spesies Heterometrus lepturus dengan dengan nilai indeks keanekaragaman jenis hanya 0,011, rendahnya indeks keanekaragaman jenis pada hewan kalajengking ini dikarenakan habitatnya yang kurang cocok untuk menjalankan kehidupannya, dimana lokasi penelitian adalah lahan pertanian yang sedikit terdapat serasah dibandingkan dengan hutan. Wibowo \& Slamet (2014) menyatakan makrofauna tanah sangat dipengaruhi oleh kondisi lingkungan sekitar. Perubahan lingkungan akan berdampak pada keberadaan makrofauna tanah, baik secara langsung maupun tidak langsung. Hadi \& Rohman (2011) menambahkan bahwa habitat asli kalajengking adalah meliputi kulit kayu, batang kayu, bebatuan dan pada retakan batu.

Tabel 3. Hasil Pengukuran Faktor Abiotik di Perkebunan Kopi Desa Batu Kalung

\begin{tabular}{llc}
\hline No. & Faktor Abiotik & Rata-Rata \\
\hline 1. & Suhu $\left({ }^{\circ} \mathrm{C}\right)$ & $28^{\circ} \mathrm{C}$ \\
2. & pH Tanah & 5,8 \\
3. & Kelembaban Udara & $67 \%$ \\
\hline
\end{tabular}

Berdasarkan Tabel 3 hasil pengukuran suhu tanah rata-rata pada lahan perkebunan kopi desa Batu Kalung ini diperoleh $28^{\circ} \mathrm{C}$, dengan nilai suhu dapat mempengaruhi kehidupan keanekaragaman makrofauna tanah di lokasi penelitian yang rendah. Wibowo \& Slamet (2014) menjelaskan faktor-faktor yang diduga kuat mempengaruhi makrofauna tanah setiap lingkungan. Suhu tanah yang berkisar 19$23^{\circ} \mathrm{C}$ kondisi suhu yang seperti itu diduga sangat mempengaruhi keberadaan makrofauna tanah. Suin (2012) menambahkan suhu tanah juga merupakan salah satu faktor fisika tanah yang sangat menentukan kehadiran dan kepadatan organisme tanah, dengan demikian suhu tanah akan sangat menentukan tingkat dekomposisi material organik tanah.

Hasil dari pengukuran $\mathrm{pH}$ tanah pada lokasi penelitian rata-rata 5,8, hal ini menunjukkan bahwa $\mathrm{pH}$ pada lahan perkebunan kopi tersebut rendah atau asam karena $\mathrm{pH}<7$. Sehingga $\mathrm{pH}$ yang rendah tidak cocok untuk kehidupan makrofauna tanah. Nurrohman et al. (2015) menyatakan bahwa sebagian besar fauna tanah 
menyukai pH berkisar 6-7 karena ketersediaan unsur hara yang cukup tinggi. Suin (2012) menjelaskan bahwa pengukuran $\mathrm{pH}$ tanah sangat penting dalam ekologi hewan tanah karena keberadaan dan kepadatan hewan tanah sangat bergantung $\mathrm{pH}$ tanah. Hewan tanah ada yang memilih hidup pada tanah yang pHnya asam dan ada juga senang pada $\mathrm{pH}$ basa.

Dari hasil pengukuran kelembaban tanah rata-rata pada lahan perkebunan kopi tersebut mencapai $67 \%$, hal ini menunjukkan tingkat kelembaban sedang. kelembaban tanah menunjukkan pengaruh terhadap keberadaan dan keragaman makrofauna tanah pada lokasi penelitian sehingga didapatkan hasil indeks keanekaragaman yang kurang. Suin (2012) menyatakan kepadatan hewan tanah juga sangat sangat tergantung pada kadar air, umumnya pada tanah yang rendah kadar airnya kepadatan hewan tanah juga rendah, keberadaan makrofauna tanah sangat tergantung oleh faktor lingkungan abiotik (suhu, kadar air, $\mathrm{pH}$ tanah, kadar organik tanah) dan faktor lingkungan biotik (organisme lain di sekitarnya, seperti mikroflora, tumbuh-tumbuhan, dan golongan hewan lainnya).

\section{SIMPULAN}

Berdasarkan penelitian yang telah dilakukan di perkebunan kopi Desa Batu Kalung Kecamatan Muara Kemumu ditemukan sebanyak 13 spesies yang termasuk dalam 11 famili dan 9 ordo. Keanekaragaman makrofauna tanah di Batu Kalung Kecamatan Muara Kemumu tergolong rendah.

\section{REFERENSI}

Anwar, E.K \& R. Cinta Badia Ginting. (2013). Mengenal Fauna Tanah Dan Cara Identifikasinya. Badan Penelitian dan Pengembangan Pertanian Kementrian Pertanian. Jakarta : IAARD Press.

Habwan, M.Ihsan. (2017). Komposisi Komunitas Makrofauna Tanah Pada Hutan Sekunder Dan Agroforestri Kopi Di Desa Pengambaten Kecamatan Menek Kabupaten Karo. Skripsi Universitas Sumatera Utara.

Hadi, M. \&Rohman, A.F. (2011). Fauna Kalajengking (Arachnida : Scorpiones) di Pemukiman Jatiluhur Jatingaleh Semarang. Jurnal Sains dan Matematika, 4(2), 19-32

Hanafiah, K.A. (2012). Dasar-Dasar Ilmu Tanah. Jakarta. RajaGrafindo Persada.

Hasyimuddin, Syahribulan \& Andi A. U. (2017). Peran Ekologis Serangga Tanah di Perkebunan Patallassang Kecamatan Patallassang Kabupaten Gowa Sulawesi Selatan. Seminar Nasional Biology for Life. Gowa: Jurusan Biologi, Fakultas Sains dan Teknologi, UIN Alauddin Makassar.

Hilwan, I \& Handayani, E.P. (2013). Keanekaragaman Mesofauna dan Makrofauna Tanah pada Areal Bekas Tambang Timah di Kabupaten Belitung, Provinsi Kepulauan Bangka-Belitung. Jurnal Silvikultur Tropika, 4(1), 35-41.

Imawan, Hardi. (2013). Keanekaragaman Makrofauna Tanah Pada Vegetasi Pohon Pinus (Pinus merkusii) di Kesatuan Pemangkuhan Hutan (KPH) Wisata Alam Coban Rondo Kecamatan Pujon Kabupaten Malang Skripsi Pendidikan Biologi UMM. Tidak Diterbitkan. Malang.

Nurrohman, E., Abdulkadir R. \& Sri W. (2015). Keanekaragaman Makrofauna Tanah di Kawasan Perkebunan Coklat (Theobroma cacao L.) Sebagai Bioindikator Kesuburan Tanah dan Sumber Belajar Biologi. Jurnal Pendidikan Biologi Indonesia, 1(2), 197-208. 
Pemerintah Desa. (2017). Profil Batu Kalung. Kecamatan Kemumu. Kabupaten Kepahiang.

Peritik, M. Z. (2010). Keanekaragaman Makrofauna Tanah Pada Berbagai Pola Agroforesti Lahan Miring Di Kabupaten Wonogiri Jawa Tengah. Skripsi Biologi Universitas Sebelas Maret Surakarta. Tidak di Publikasikan.

Prasetyo, A. Ulfa Y. R., Rini W., Esa C. D. \& Safina A. A. (2016). Struktur Komunitas Mesofauna Dan Makrofauna Tanah di Gua Groda Gunung Kidul. Jurnal Sains Dasar, 5(2), 133-139.

Rousseau L, Fonte SJ, Tellez O, Hoek RVD, \& Lavelle P. (2013). Soil Macrofauna as Indicator of Soil Quality and Land Use Impact in Smallholder Agroecosystems of Western Nicaragua. Ecological indicators, 27(2013), 71-82.

Saputra, A \& Agustina, Putri. (2019). Keanekaragaman Makrofauna Tanah Di Universitas Sebelas Maret. Seminar Nasional Pendidikan Biologi dan Saintek (SNPBS) ke-IV. Surakarta: Universitas Muhammadiyah Surakarta.

Sugiyarto, E., M. Mahajoeno, E. Sugito, Y. Eko, H. Agustina, L. (2010). Preferensi Berbagai Jenis Makrofauna Tanah Terhadap Sisa Bahan Organik Tanaman Pada Intensitas Cahaya Berbeda.Jurnal Biodiversitas, 7(4), 96-100.

Suheriyanto, D. (2012). Keanekaragaman Fauna Tanah Di Taman Nasional Bromo Tengger Semeru Sebagai Bioindikator Tanah Bersulfur Tinggi. Malang. Jurnal Sainstis,1 (2), 34-40.

Suin , N.M. (2012). Ekologi Hewan Tanah. Jakarta: Bumi Aksara.

Wibowo, C. \& Slamet, S.A. (2014). Keanekaragaman Makrofauna Tanah Pada Berbagai Tipe Tegakan Di Areal Bekas Tambang Silika Di Holcim Educational Forest, Sukabumi, Jawa Barat. Bogor. Jurnal Silvikultur Tropika, 5 (1), 43-48.

Yulipriyanto, H. (2010). Biologi Tanah dan Strategi Pengelolaanya. Yogyakarta. Graha Ilmu. 